\title{
Analysis of Medium- to Long-Term Natural Gas Demand and Supply
}

This section explores various aspects of the development of industry and the economy, and the changes in supply and demand of different energy sources, considered in combination with projected changes in economic growth, advances in technology and shifts in industrial structure. The aim is to determine the medium- to long-term demand and supply of natural gas and other energy sources in China.

\subsection{The Natural Gas Supply-Demand Model}

In order to analyse and predict the future of natural gas demand, a Computable General Equilibrium (CGE) model was devised to reflect medium- to long-term economic growth and changes in industrial structure, in terms of total demand for energy sources and the interchangeability between natural gas and other energy sources. The CGE model relies on general equilibrium theory, using actual economic data as the initial equilibrium, and reflects optimised decision-making by the market components

\footnotetext{
* This chapter was overseen by Zhaoyuan Xu from the Development Research Center of the State Council and Martin Haigh from Shell International, with contributions from Baosheng Zhang and Shouhai Chen from the China University of Petroleum, Lianzeng Zhao from the China Petroleum Planning Research Institute, Linji Qiao from ENN and Juan Han from Shell China. Other members of the research group participated in discussions and revisions.
}

(manufacturers, consumers, government departments). Compared to general economic models, CGE models are more often used for simulating the effect that policies have on the economy, whether direct or indirect, making them an effective tool for analysing policies. The CGE model used in this study is based on the Computable General Equilibrium model developed and maintained over time by China's State Council's Development Research Center (DRC-CGE) for dynamically simulating the economy of China. The development of the model began in 1997; it has been perfected over the years and applied to studies of the effects of China joining the World Trade Organization, infrastructure construction, energy conservation, emission reduction, urbanisation and other policies.

\subsubsection{Basic Characteristics of the Model}

The model uses 2010 as the base year and, adopting the Social Accounting Matrix based on 2010 input-output tables of China for basic data, simulates the economy from 2010 to 2025. it includes economic activities from various sectors, reflecting five aspects in particular:

- the manufacturing activities of various business sectors in the economy, and the demands stemming from such manufacturing activities; 


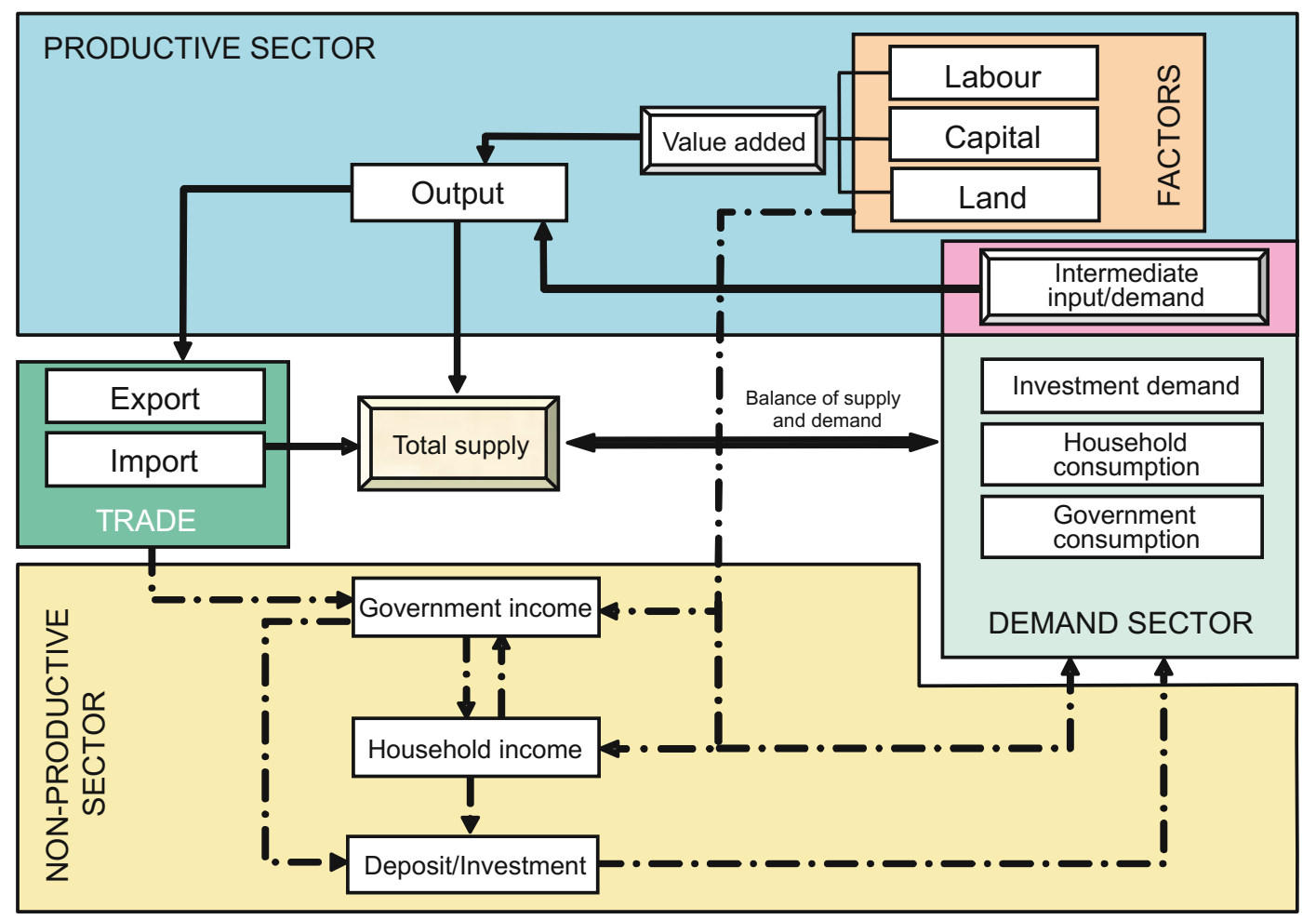

Fig. 5.1 Main structures of the CGE model used in this study

- the economy's demand for products: the total demand coming from the everyday activities of the citizens, the government and businesses, as well as from other countries (regions), including the three major demands of consumption, investment and exports;

- the income, consumption and reserves of each major economic body;

- foreign trade; and

- dynamic economic growth and development.

The relationships of these factors are shown in Fig. 5.1.

In this study, the model includes all of the 46 production industries (as seen in Table 5.1), specifically 1 from agriculture, 5 from mining, 22 from manufacturing, 3 from public works and construction, and 14 from the service sector. These industries illustrate the production activities of various business categories.

\subsubsection{Main Intensifications and Adjustments Made Towards Studies of Natural Gas in This Model}

Compared to typical CGE models, the one used in this study made the following major changes to reflect influences on the supply and demand equilibrium of natural gas.

\section{Detailed representation of primary energy production}

To better reflect the input-output and interchangeability of various energy sources, this study takes into account coal mining and processing, oil drilling, natural gas extraction, oil refining, coking, coal power, natural gas power, hydroelectricity, wind power, solar power, 
Table 5.1 Subdivision of industries in the model of this study

\begin{tabular}{|c|c|c|c|c|c|}
\hline Number & Industry & Number & Industry & Number & Industry \\
\hline 1 & $\begin{array}{l}\text { Agriculture, forestry } \\
\text { and fishing industry }\end{array}$ & 25 & $\begin{array}{l}\text { Non-metal mineral product } \\
\text { industry }\end{array}$ & 49 & $\begin{array}{l}\text { Heat production and } \\
\text { supply industry }\end{array}$ \\
\hline 2 & $\begin{array}{l}\text { Coal mining and } \\
\text { preparation industry }\end{array}$ & 26 & $\begin{array}{l}\text { Ferrous metals smelting } \\
\text { industry }\end{array}$ & 50 & $\begin{array}{l}\text { Natural gas production } \\
\text { and supply industry }\end{array}$ \\
\hline 3 & Petroleum industry & 27 & Steel rolling industry & 51 & Water supply industry \\
\hline 4 & $\begin{array}{l}\text { Natural gas drilling } \\
\text { industry }\end{array}$ & 28 & $\begin{array}{l}\text { Non-ferrous metals smelting } \\
\text { and rolling industry }\end{array}$ & 52 & Construction industry \\
\hline 5 & $\begin{array}{l}\text { Ferrous metals mining } \\
\text { industry }\end{array}$ & 29 & Metal products industry & 53 & Logistics industry \\
\hline 6 & $\begin{array}{l}\text { Non-ferrous metals } \\
\text { mining industry }\end{array}$ & 30 & $\begin{array}{l}\text { Equipment manufacturing } \\
\text { industry }\end{array}$ & 54 & $\begin{array}{l}\text { Urban public } \\
\text { transportation industry }\end{array}$ \\
\hline 7 & $\begin{array}{l}\text { Non-metal and other } \\
\text { mining industry }\end{array}$ & 31 & $\begin{array}{l}\text { Special equipment } \\
\text { manufacturing industry }\end{array}$ & 55 & $\begin{array}{l}\text { Other transportation and } \\
\text { warehouse industry }\end{array}$ \\
\hline 8 & $\begin{array}{l}\text { Food and alcoholic } \\
\text { beverage industry }\end{array}$ & 32 & $\begin{array}{l}\text { Railway transportation and } \\
\text { equipment manufacturing } \\
\text { industry }\end{array}$ & 56 & Postal industry \\
\hline 9 & Tobacco industry & 33 & Car manufacturing industry & 57 & $\begin{array}{l}\text { Information transmission, } \\
\text { computer and software } \\
\text { industry }\end{array}$ \\
\hline 10 & $\begin{array}{l}\text { Textiles processing } \\
\text { industry }\end{array}$ & 34 & $\begin{array}{l}\text { Ship and flotation device } \\
\text { manufacturing industry }\end{array}$ & 58 & $\begin{array}{l}\text { Distribution and retail } \\
\text { industry }\end{array}$ \\
\hline 11 & $\begin{array}{l}\text { Textiles, knitting and } \\
\text { manufacturing industry }\end{array}$ & 35 & $\begin{array}{l}\text { Other transportation } \\
\text { equipment manufacturing } \\
\text { industry }\end{array}$ & 59 & Hospitality industry \\
\hline 12 & $\begin{array}{l}\text { Clothing, shoe and hat } \\
\text { manufacturing industry }\end{array}$ & 36 & $\begin{array}{l}\text { Electrical appliances } \\
\text { industry }\end{array}$ & 60 & Financial industry \\
\hline 13 & $\begin{array}{l}\text { Leather, fur, feathers } \\
\text { (down) and related } \\
\text { products industry }\end{array}$ & 37 & $\begin{array}{l}\text { Electricity supply and } \\
\text { distribution and control } \\
\text { equipment manufacturing } \\
\text { industry }\end{array}$ & 61 & Real estate industry \\
\hline 14 & $\begin{array}{l}\text { Carpentry and furniture } \\
\text { manufacturing industry }\end{array}$ & 38 & $\begin{array}{l}\text { Household electrical and } \\
\text { non-electrical equipment } \\
\text { manufacturing industry }\end{array}$ & 62 & $\begin{array}{l}\text { Rental and commercial } \\
\text { services industry }\end{array}$ \\
\hline 15 & $\begin{array}{l}\text { Paper making and } \\
\text { printing industry }\end{array}$ & 39 & $\begin{array}{l}\text { Other electrical machinery } \\
\text { and equipment } \\
\text { manufacturing industry }\end{array}$ & 63 & $\begin{array}{l}\text { Research, testing and } \\
\text { development industry }\end{array}$ \\
\hline 16 & $\begin{array}{l}\text { Education and physical } \\
\text { education equipment } \\
\text { manufacturing industry }\end{array}$ & 40 & $\begin{array}{l}\text { Communication equipment } \\
\text { and radar manufacturing } \\
\text { industry }\end{array}$ & 64 & $\begin{array}{l}\text { Integrated technical } \\
\text { services industry }\end{array}$ \\
\hline 17 & $\begin{array}{l}\text { Oil refinery and nuclear } \\
\text { fuel processing industry }\end{array}$ & 41 & $\begin{array}{l}\text { Computer manufacturing } \\
\text { industry }\end{array}$ & 65 & $\begin{array}{l}\text { Water conservancy, } \\
\text { environment and public } \\
\text { facilities management } \\
\text { industry }\end{array}$ \\
\hline 18 & Coking industry & 42 & $\begin{array}{l}\text { Electronic component } \\
\text { manufacturing industry }\end{array}$ & 66 & $\begin{array}{l}\text { Personal and other } \\
\text { services industry }\end{array}$ \\
\hline 19 & Chemical industry & 43 & $\begin{array}{l}\text { Home audio-visual } \\
\text { equipment manufacturing } \\
\text { industry }\end{array}$ & 67 & Education \\
\hline 20 & $\begin{array}{l}\text { Fertilisers and } \\
\text { agricultural chemicals }\end{array}$ & 44 & $\begin{array}{l}\text { Other electronics } \\
\text { manufacturing industry }\end{array}$ & 68 & $\begin{array}{l}\text { Health, social security and } \\
\text { benefits industry }\end{array}$ \\
\hline
\end{tabular}


Table 5.1 (continued)

\begin{tabular}{|c|c|c|c|c|c|}
\hline Number & Industry & Number & Industry & Number & Industry \\
\hline 21 & $\begin{array}{l}\text { Synthesised material } \\
\text { manufacturing industry }\end{array}$ & 45 & $\begin{array}{l}\text { Measuring instruments and } \\
\text { devices manufacturing } \\
\text { industry }\end{array}$ & 69 & $\begin{array}{l}\text { Cultural, physical } \\
\text { education and } \\
\text { entertainment industry }\end{array}$ \\
\hline 22 & $\begin{array}{l}\text { Special chemical } \\
\text { products manufacturing } \\
\text { industry }\end{array}$ & 46 & $\begin{array}{l}\text { Cultural, office machinery } \\
\text { manufacturing industry }\end{array}$ & 70 & $\begin{array}{l}\text { Public management and } \\
\text { social organisation }\end{array}$ \\
\hline 23 & $\begin{array}{l}\text { Other chemical } \\
\text { products }\end{array}$ & 47 & $\begin{array}{l}\text { Handicrafts and other } \\
\text { products (including waste } \\
\text { products) industry }\end{array}$ & & \\
\hline 24 & $\begin{array}{l}\text { Plastics and rubber } \\
\text { products }\end{array}$ & 48 & $\begin{array}{l}\text { Power generation and } \\
\text { supply industry }\end{array}$ & & \\
\hline
\end{tabular}

nuclear power, natural gas heating, coal heating and natural gas processing, giving a total of 14 types of energy source, thus better reflecting the interchangeability of energy sources, especially the potential of natural gas to replace other energy sources.

Based on the national energy policy, this model separately configured production functions and development scales of different energy sources, such as installed capacity of nuclear energy, hydroelectricity, solar power and others, in order to ensure that they are in accordance with national planned goals.

\section{Detailed representation of characteristics of the demands of the various sectors towards natural gas}

To examine natural gas demand in detail, this study subdivided industries, in particular industries with higher demand for natural gas. For example, the chemical industry was subdivided in order to reflect its demand for natural gas as a raw material and the transportation industry was subdivided in order to reflect its demand for natural gas.

\subsection{Simulation Scenarios for Analysis Simulations of Natural Gas Demand}

To carry out the simulated analysis of natural gas supply and demand, and to compare various policies, this study has devised two different scenarios: one is the standard scenario, where the current basic trends of economic growth are reflected, the other is the policy-driven scenario, which includes the effects of government policies favourable towards natural gas demand.

\subsubsection{Key Assumptions of the Standard Scenario}

In the standard scenario, backed by clearly designed policies, relatively assertive growth factors are observed in the Chinese economy. On the other hand, under the influence of ambitious government policies regarding environmentally friendly development and innovation, there are the following significant changes to the growth factors:

- Changes in total population and age structure reflecting the influence of the newest population policy adjustments (one-child policy, two-child policy) in terms of medium- to long-term total population and workforce. The population of China peaks at around 2032, when it will be around 1.463 billion, with the workforce peaking between 2017 and 2027, at around 1 billion.

- Growth in personal consumption expenditure, brought about by an increase in income levels. Particularly remarkable is the reduction in the percentage of expenditure taken up by food and other consumable goods, while travel, leisure, education and expenditure for other services continue to increase. 
- Policies promoting energy conservation and emission reduction, influenced by the attempt to bring about a "new normal" and a variety of activities targeted at alleviating atmospheric pollution, where the government continues to push for energy conservation and consumption reduction, raising energy efficiency by between 3 and $2 \%$ points each year (a higher rate of increase at first, followed by a lower one).

- The new urbanisation policies progress smoothly, and more of the rural population are now living in cities. The urbanisation rate will hopefully reach $70 \%$ in 2030 and $75 \%$ in 2050 .

- Personal savings remain at high levels, but this is expected to gradually reduce as personal income and level of social security provision improve. By 2030, the personal savings rate of urban populations should fall by $13 \%$, from the current rate of $38 \%$ to around $25 \%$.

In addition to the above factors, optimised policies include policies that concentrate in particular on transformation of the mode of economic development:

- A more significant ratio of renewable energy usage, mainly represented by rapid developments in non-fossil fuel energy sources such as nuclear power, wind power and solar power. For nuclear power, the installed capacity of 14.61 million MW in 2013 will quickly grow to 58 million MW by 2020 , reaching 150 million MW by 2030 and 400 million MW by 2050 . Installed capacity of hydroelectric power plants was 280 million MW in 2013, and will rise to 340 million MW in 2020, 400 million MW by 2030 and around 450 million MW by 2050. Other energy sources such as wind power and solar power will also grow at similar speeds.

- The government places great importance on innovation-driven development, enabling remarkable breakthroughs in improving business innovation, the results of which will contribute to an increased significance of improvement in core areas driving economic growth, which will become evident by the 13th and 14th Five-Year Plans, at which stage secondary industry in China will have a high sustainable all-factor growth rate of $4 \%$.

- Mitigation of overcapacity is relatively smooth, allowing industry to grow continuously. This can be observed in the slowing growth in investment in heavy and chemicals industry while output growth stabilises, a trend that will benefit sustained development of the industry.

- The nurturing of tertiary industries, in particular the hastening of the development of productive service industries and tertiary industries, which will be beneficial in bringing in new investment to monopolistic industries previously difficult to access, such as finance, logistics, education and health.

- As a result of financial reforms, the proportion of the national economy accounted for by private income increases; this is advantageous because of raised income levels and the improved ratio of consumption and investment in the economy.

\subsubsection{Key Assumptions of the Policy-Driven Scenario}

In the policy-driven scenario, apart from making the same assumptions as the standard scenario, the government will also levy a carbon tax on coal, oil and natural gas - fossil fuels that result in greenhouse gas emissions. Pricing for this carbon tax collected through carbon trading will be implemented in 2015 for coal. The carbon price (or tax rate) for the first year will be $10 \%$ of price, rising to $20 \%$ in the second year, then remaining at $30 \%$ thereafter. The tax rate for petroleum (including both crude oils and refined oils) is the tax rate for coal multiplied by the difference in carbon emission rates, which works out at 0.64 times the tax rate for carbon price for coal, while the rate for natural gas is 0.2 times the rate for coal, converted based on a coal price of $500 \mathrm{CNY} /$ ton once the rate reaches $30 \%$ (ad valorem). This is equivalent to a carbon emissions tax (or achieving a carbon price through 
carbon trading of an equivalent amount) of CNY 60 for every ton of carbon dioxide where coal is concerned.

\subsection{Natural Gas Supply and Demand in the Standard Scenario}

\subsubsection{Speed of Economic Growth and International Comparison}

Under the assumptions of the standard scenario, China will retain a relatively fast growth rate in the future. In the two years after the 12th Five-Year Plan, the average economic growth rate is expected to be around $7.3 \%$, with GDP growth during the 13th Five-Year Plan at around 6.66 and $5.56 \%$ from 2021 to 2025 . In the period between 2026 and 2030, economic growth is expected to be around $4.64 \%$, around $3.47 \%$ from 2031 to 2040 and around $2.73 \%$ from 2041 to 2050 (Table 5.2).

Based on simulation results, the per capita GDP of China will continue rising at a relatively fast rate. For example, by around 2020, per capita GDP in China is hoped to reach $\$ 10,000$ (in 2013 figures, and taking into account an average annual $0.5 \%$ appreciation of the CNY), while by 2030 per capita GDP in China could reach $\$ 20,000$, and $\$ 40,000$ by 2050 , thus achieving a similar level to that current in Japan. If the comparison is made using purchasing power parity, China's development level will be even higher (Fig. 5.2).

Table 5.2 Growth speed and growth momentum in the standard scenario

\begin{tabular}{|l|c|c|c|c|c|c|c|}
\hline Year & 2013 & $2014-2015$ & $2016-2020$ & $2021-2025$ & $2026-2030$ & $2031-2040$ & $2041-2050$ \\
\hline GDP & 7.68 & 7.31 & 6.65 & 5.55 & 4.63 & 3.46 & 2.73 \\
\hline $\begin{array}{l}\text { Speed of growth } \\
\text { in workforce }\end{array}$ & 0.3 & 0.1 & -0.2 & -0.3 & -0.5 & -0.7 & -0.4 \\
\hline $\begin{array}{l}\text { Speed of growth } \\
\text { in capital deposit }\end{array}$ & 11.6 & 10.9 & 9.3 & 7.7 & 6.5 & 4.8 & 3.2 \\
\hline
\end{tabular}

Data source Based on calculation results

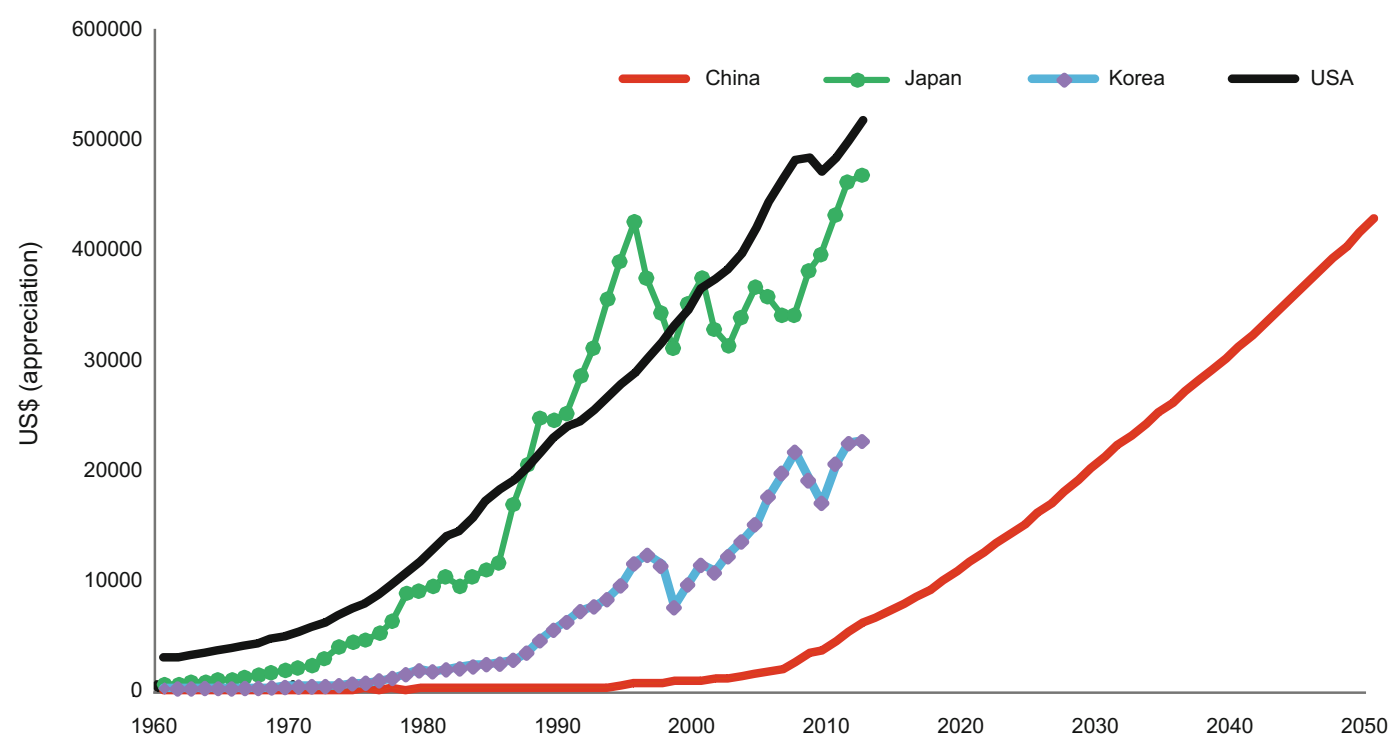

Fig. 5.2 Development levels in China and international comparisons in the standard scenario. Data source Figures for China after 2013 based on model calculation results, other figures from Wind data 
In the standard scenario, the speed of growth of China's economy is still higher than the historical speed of other "catch-up economies", while also exhibiting the usual sustained growth characteristics encountered with "catch-up" economies. For example, before 2020, there is a possibility that per capita GDP growth in China can be kept above $6 \%$, exceeding the historical figures for Japan, Taiwan and the United States, only being lower than historical figures for specific years in South Korea. The same goes for the period from 2020 to 2030, when growth speed in China will far exceed historical figures for other countries.

Similar results were obtained from long-term purchasing power parity calculations using the World Bank's International Comparison Program. Using this programme, per capita GDP in China will reach the level of South Korean per capita GDP by 2030 and by 2035 it will be on a par with Japanese per capita GDP, exceeding per capita GDP in the USA in 2050 (Figs. 5.3 and 5.4).

\subsubsection{Mid- to Long-Term Changes in Industrial Structures}

The simulation shows that the tertiary industry ratio will continue to rise. In 2013, the tertiary industry ratio was $46.1 \%$, which is significantly lower than the level of most countries at a similar level of development. In 2015, it rises to around $48.1 \%$, and from 2015 to 2020 it will rise by $4.9 \%$, possibly exceeding $60 \%$ by 2030 , reaching around $65 \%$ in 2050 (Table 5.3).

From experience gained with economic growth in other countries, as the level of development rises, the ratio of non-agricultural industries also goes up, especially the tertiary industry ratio, which seems to be a general norm. Major factors pushing the tertiary industry ratio higher are the changes in people's consumer styles, increased services export ratio and rising demand for services in various sectors, as well as government spending. Deceleration of export growth also holds sway over tertiary industrial structure, since the main exports are

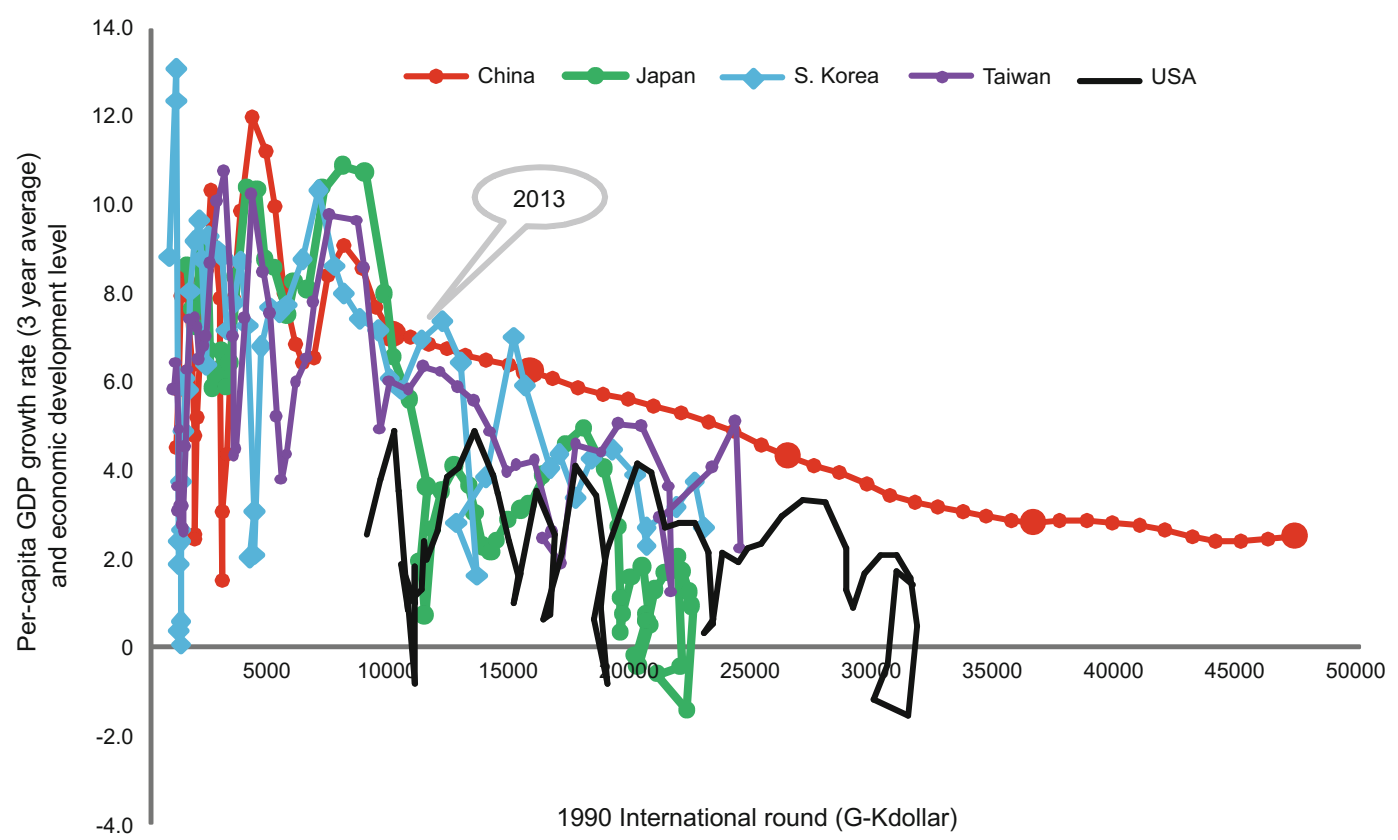

Fig. 5.3 Growth speed in China and international comparisons in the standard scenario. Description Data for Japan, South Korea, Taiwan and USA drawn from historical growth figures; horizontal axis is the international dollar calculation based on 1990 purchasing power parity calculated using Maddison's method. Data source Figures for China after 2013 based on model calculation results, other figures from Maddison 


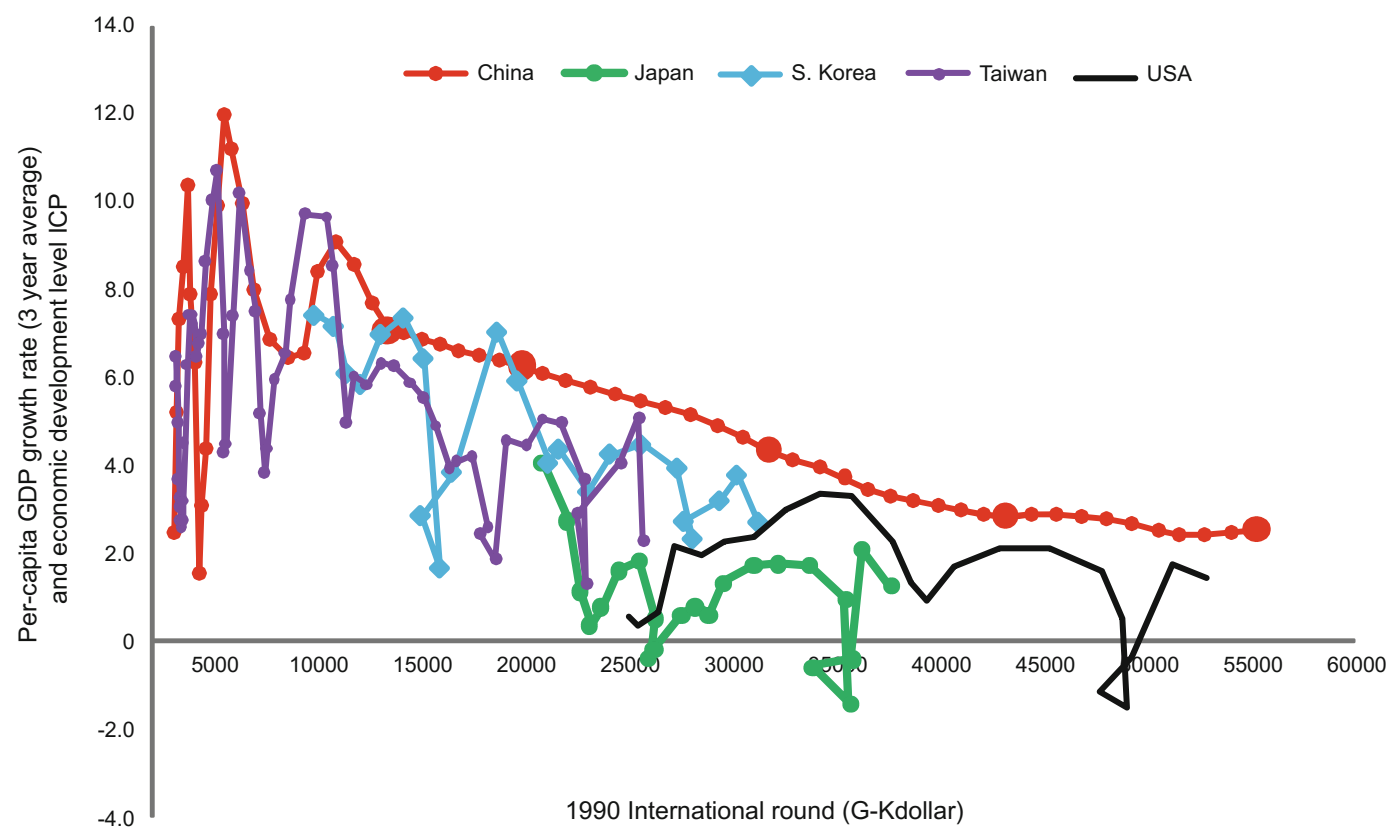

Fig. 5.4 Growth speed in China and international comparisons in the standard scenario. Data source Figures for China after 2013 based on model calculation results, other figures from Maddison

Table 5.3 Industry structures in the standard scenario

\begin{tabular}{|l|l|l|l|l|l|l|l|l|l|}
\hline Year & 2010 & 2015 & 2020 & 2025 & 2030 & 2035 & 2040 & 2045 & 2050 \\
\hline Primary industries & 10.0 & 9.0 & 7.1 & 6.2 & 5.4 & 5.0 & 4.8 & 4.8 & 5.1 \\
\hline Secondary industries & 48.2 & 43.0 & 39.8 & 35.7 & 33.4 & 32.1 & 30.8 & 30.0 & 29.3 \\
\hline Tertiary industries & 41.8 & 48.0 & 53.1 & 58.1 & 61.2 & 62.9 & 64.4 & 65.2 & 65.6 \\
\hline
\end{tabular}

Data source Results from model calculation

manufactured goods and therefore, when other conditions remain unchanged, a faster growth in exports will most likely lead to a larger corresponding secondary industry ratio (Fig. 5.5).

In the period from 2020 to 2025 , China will essentially complete the industrialisation process, entering the post-industrialisation era. Looking at the progress of industrialisation in China, the demand for heavy industries such as steel and concrete is approaching its peak, while the eastern coastal regions are on their way into the post-industrialisation stage. This development trend conforms to the strategic plans of the 18th National Congress of the Communist Party of China. This is based on two indicators: per capita GDP (which will exceed $\$ 10,000$ in 2020 (at
2013 prices) and $\$ 14,000$ in 2025 , achieving the development standard for post-industrialisation) and secondary industry's contribution to growth (which will be above $40 \%$ before 2020 , but will go through a period of significant decrease after 2020). This is similar to the situation in South Korea in the 1990s (Table 5.4).

The proportion of high energy consumption industries will begin to fall. High energy consumption industries are a major factor affecting economic structures, and if the proportion of them is high, then economic growth requires more environmental resources, leading to more serious pollution. Under optimised policies, towards the end of the 12th Five-Year Plan, it is hoped that the ratio of high energy consumption 


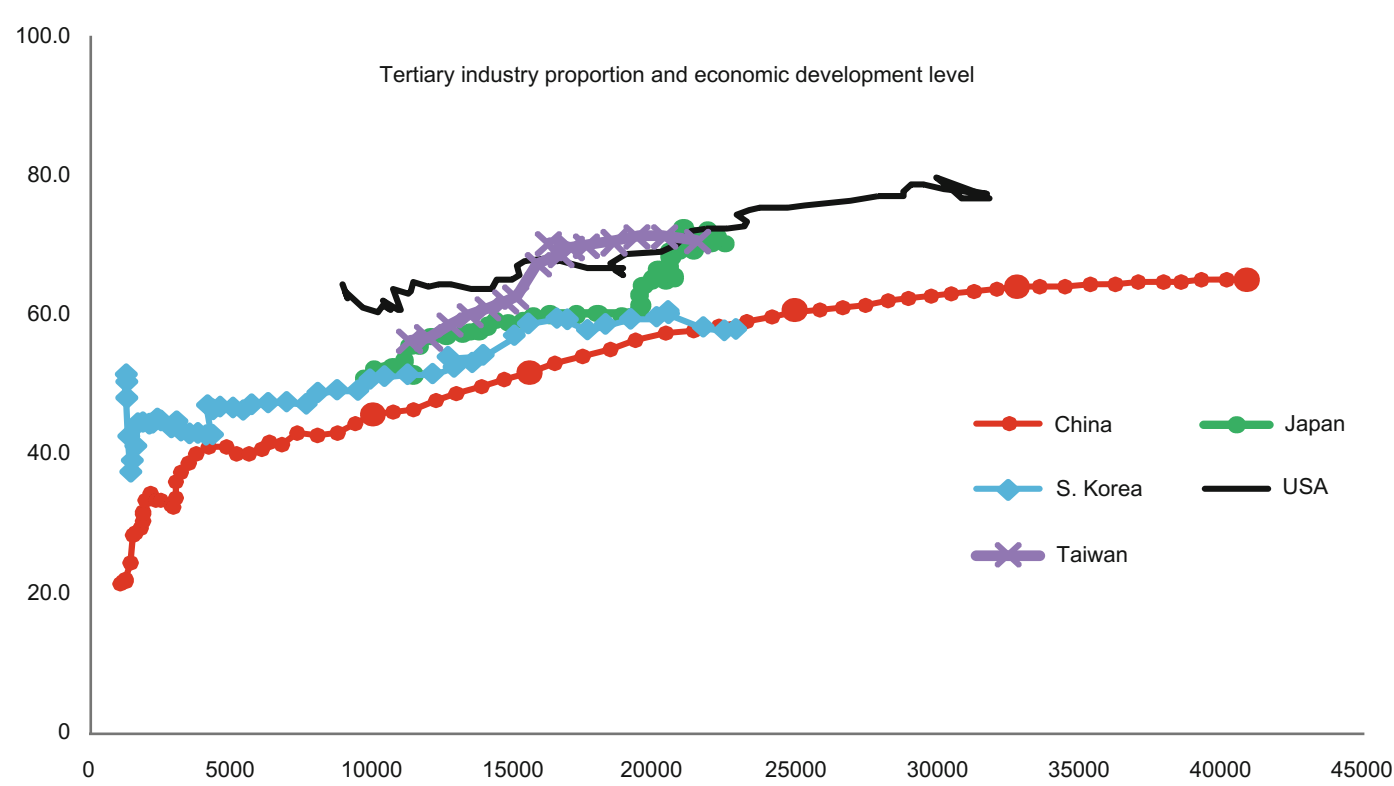

Fig. 5.5 Primary, secondary and tertiary industries in China and international comparisons in the standard scenario. Data source Results from model calculation

Table 5.4 Developed countries in the post-industrialisation era

Country
United Kingdom
United States of America
Germany
Japan

South Korea

industries will begin a continual descent, from accounting for $32.4 \%$ of all industries to accounting for $28.5 \%$ by 2030 and $24.5 \%$ by 2050 (Fig. 5.6).

\subsubsection{Energy Consumption and Structural Change}

Even though China's national industries show significant optimisation in the standard scenario, industry still accounts for a considerable proportion of the economy, and along with the rise in personal income also comes higher personal energy use. China's national energy consumption is therefore expected to increase greatly in the future. It is estimated that by 2020 total national energy source consumption will reach 5 billion tons, an annual increase of $3.4 \%$ from 2010 to

\begin{tabular}{|l|l|}
\hline Industrialisation stage & Post-industrialisation stage \\
\hline $1760-1870$ & $1950-$ \\
$1790-1900$ & $1950-$ \\
$1830-1913$ & $1970-$ \\
$1885-1973$ & $1973-$ \\
$1960-1995$ & $1995-$ \\
\hline
\end{tabular}

2020. The rise should slow between 2020 and 2030 to a $1.3 \%$ annual increase, reaching around 5.68 billion tons, and between 2030 and 2040 the rise will be further reined into $0.8 \%$ per year, but by 2040 the total national energy consumption will still reach 6.06 billion tons. Around 2045, total national energy source consumption in China will peak and in 2050 it will stabilise at around 6.1 billion tons (Fig. 5.7).

Even though total energy consumption will continue to rise, energy use per unit GDP will decline considerably, falling from 0.89 tons of coal per CNY 10,000 GDP in 2010 to 0.62 tons of coal per CNY 10,000 GDP in 2020, and then to 0.43 and 0.25 tons of coal per CNY 10,000 GDP in 2030 and 2050, respectively (Figs. 5.8 and 5.9).

There will also be great structural changes in medium- to long-term energy source production. 


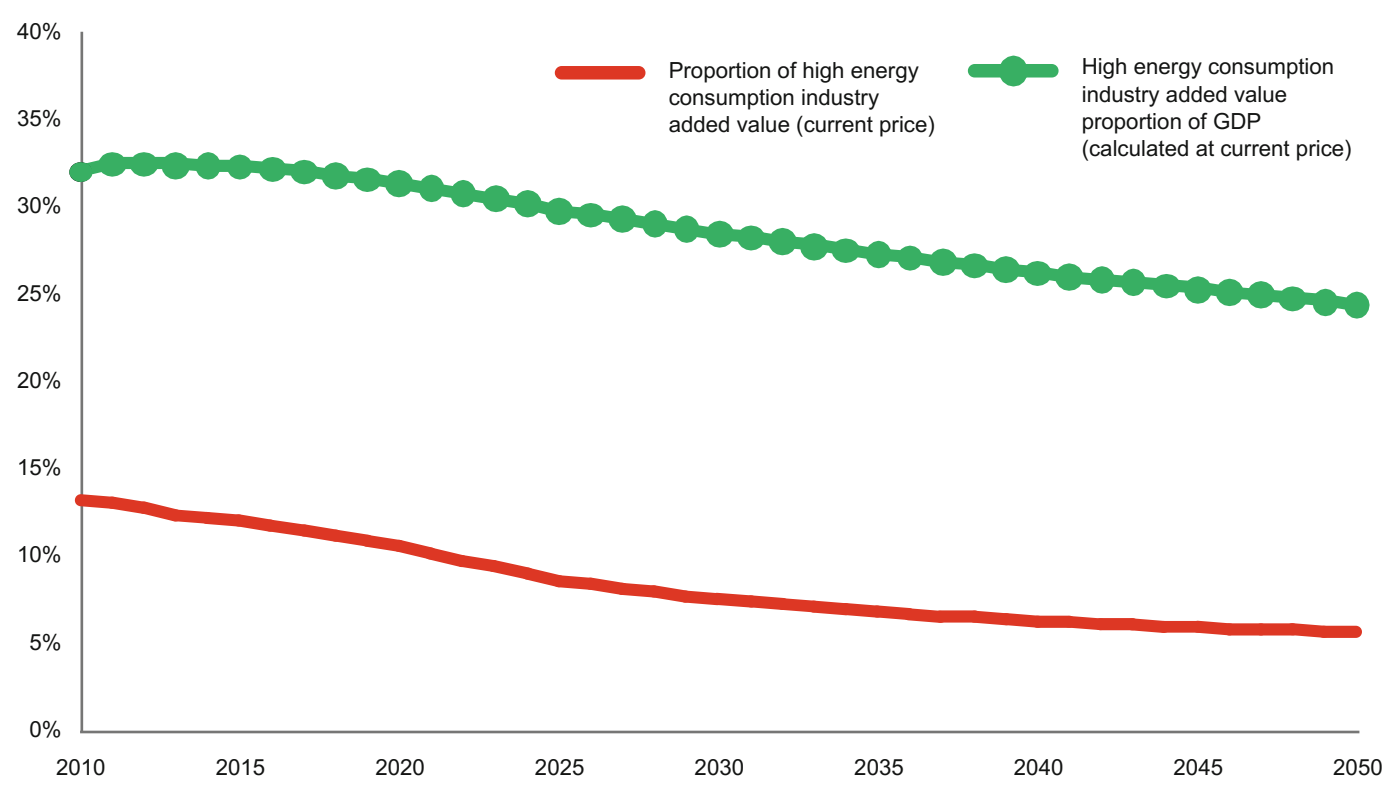

Fig. 5.6 Change in high energy consumption industry ratio under baseline scenario. Data source Results from model calculation $(\%)$

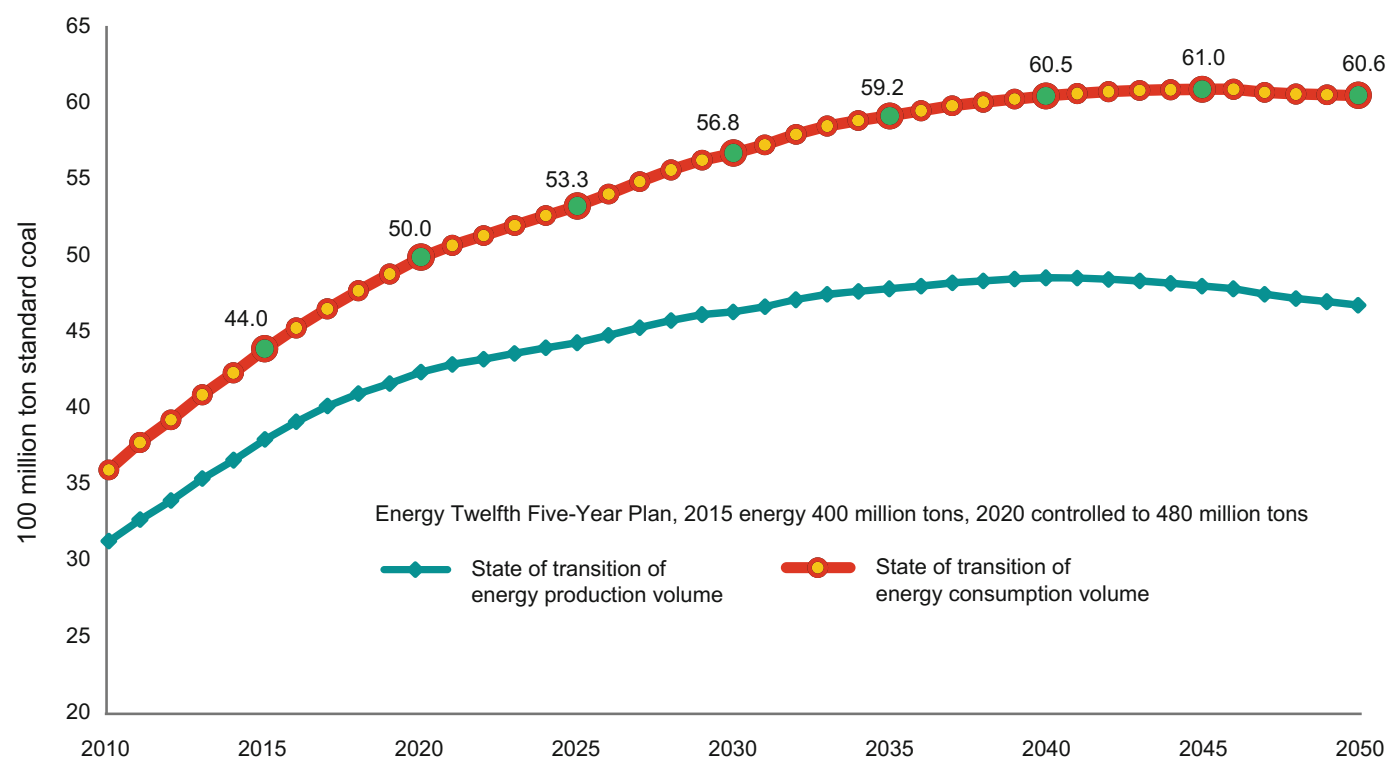

Fig. 5.7 Total energy consumption in standard scenario. Data source Results from model calculation 


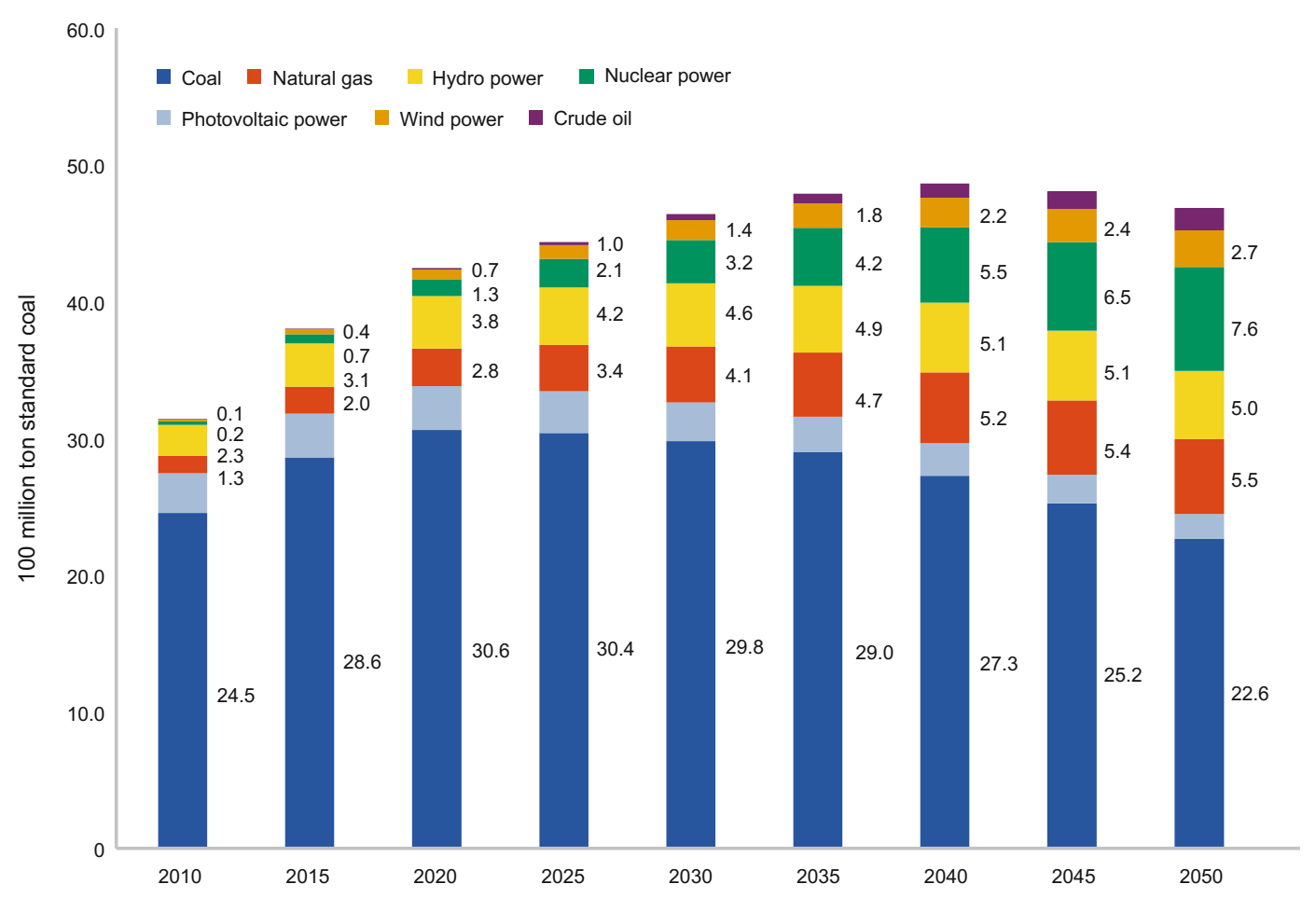

Fig. 5.8 Medium- to long-term energy production structure in China. Data source Results from model calculation

Production of the most important primary energy source, coal, will peak in around 2020 at 3.07 billion tons of standard coal, or a total of 4.3 billion tons of coal. From then onwards, coal production will fall annually, dropping to below 3 billion tons of standard coal by 2030 , below 2.5 billion tons by 2040 and around 2.26 billion tons by 2050 . As for clean energy, there will be greater development of nuclear power and hydroelectricity; hydroelectricity will grow from 230 to 380 million TSCE in 2020, and hopefully will have reached 460 million TSCE in 2030. From that point onwards, however, growth will slow to a crawl due to limitations in hydroelectric resources, reaching around 500 million TSCE by 2050 .

Nuclear power appears to have better development potential. Based on current plans, if progress is smooth, nuclear power output in China will grow from 20 to 130 million TSCE by 2020 , and then rise to 320,550 and 760 million TSCE by 2030, 2040 and 2050, respectively.
Looking at the final energy production structure, electricity will see the biggest expansion in medium- to long-term energy consumption. In 2010 electricity consumption was 1.22 billion TSCE, which is anticipated to rise to 2.65 billion TSCE into 2030 and 2.9 billion TSCE in 2050. Consumption of refined oil will also see further increases, from 520 million TSCE in 2010 to 850 million TSCE in 2030 and 940 million TSCE in 2050.

\subsubsection{Demand for Natural Gas and Main Increases in Consumption}

In the standard scenario, demand for natural gas is expected to grow rapidly. It is expected to approach 200 billion $\mathrm{m}^{3}$ in 2015, and exceed 300 billion $\mathrm{m}^{3}$ by 2020 . By 2030 it may exceed 450 billion $\mathrm{m}^{3}$, and exceed 600 billion $\mathrm{m}^{3}$ by 2050. Limited by domestic production growth, imports of natural gas (including liquid natural 


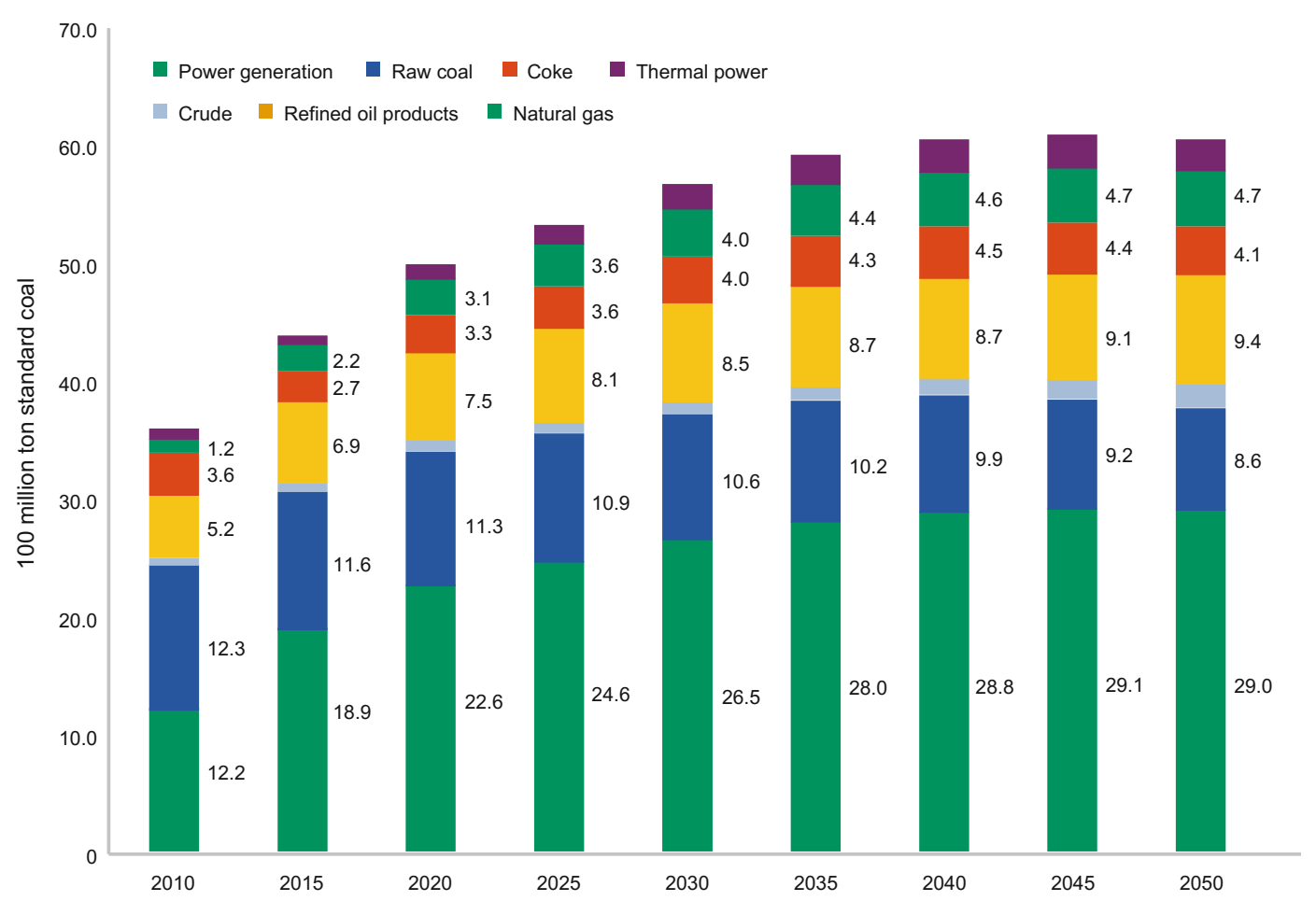

Fig. 5.9 Medium- to long-term energy consumption structure in China. Data source Results from model calculation. Note Raw coal refers to coal used for purposes other than generating electricity or coke refining

gas) are expected to see a major increase, from 50 billion $\mathrm{m}^{3}$ in 2015 to 100 billion $\mathrm{m}^{3}$ by 2020 and 180 billion $\mathrm{m}^{3}$ by 2030, stabilising by 2040 at around 200 billion $\mathrm{m}^{3}$ (Fig. 5.10).

Although fast growth is expected, growth in other energy sources, and in particular power generation, is rising, therefore the ratio of total energy sources accounted for by natural gas still lags quite a long way behind target levels. It is expected that natural gas will make up $6.0 \%$ of total energy sources by 2015 , which is somewhat less than the goal of $7.15 \%$ set out in the 12th Five-Year Plan. In 2020 it will be $8.0 \%$, which is still lower than the planned goal of $10 \%$ (Fig. 5.11).

In terms of the main areas where natural gas consumption is growing, the most important is gas use in power generation. If use of natural gas in power generation becomes economically competitive, allied with strengthened attempts to improve air quality, it is likely that natural gas use in power generation may rise from 25 billion $\mathrm{m}^{3}$ in 2015 to 50 billion $\mathrm{m}^{3}$ by 2020 , and the figure should then double and exceed 100 billion $\mathrm{m}^{3}$ by 2030, finally stabilising after 2040 at around the 160 billion $\mathrm{m}^{3}$ mark. Other than natural gas use in power generation, there are three other major natural gas uses: central heating, transport and the chemical industry.

In the medium to long term, to achieve green, clean power generation it is essential that power source structures are optimised. One major aspect of the optimisation of generation would be a reduction in output of coal-based generation and a drop in the proportion of the total resources that it accounts for. Based on simulation analysis, the standard scenario is that coal power generation in China will peak at 5.1 trillion $\mathrm{kWh}$ in around 2020 and then decline from there on, to around 4.9 trillion $\mathrm{kWh}$ by 2030 , going down further to 4.1 trillion $\mathrm{kWh}$ by 2040 and further still to 3.2 trillion $\mathrm{kWh}$ in 2050.

The reduction in coal power generation must be based on rapid developments in clean power 


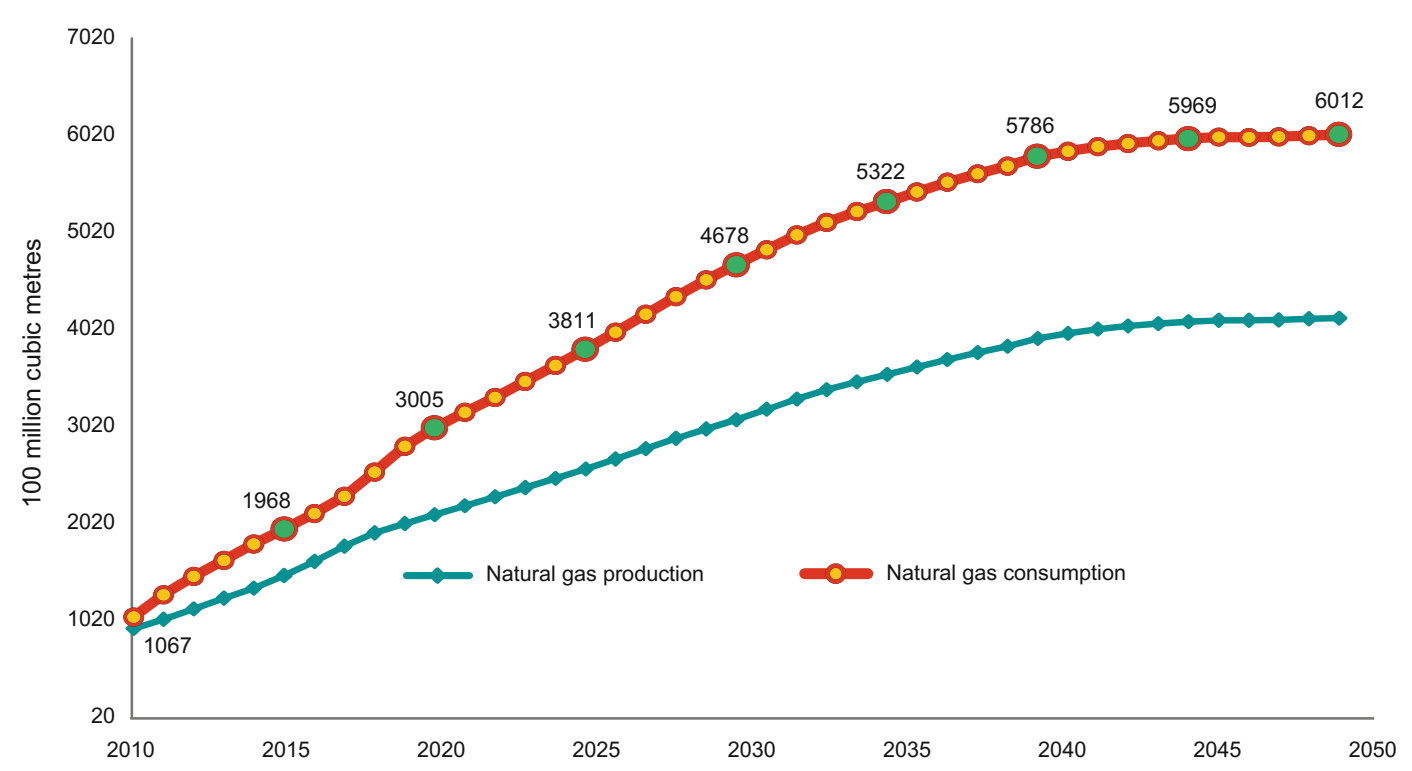

Fig. 5.10 Natural gas production and consumption in the standard scenario. Data source Results from model calculation

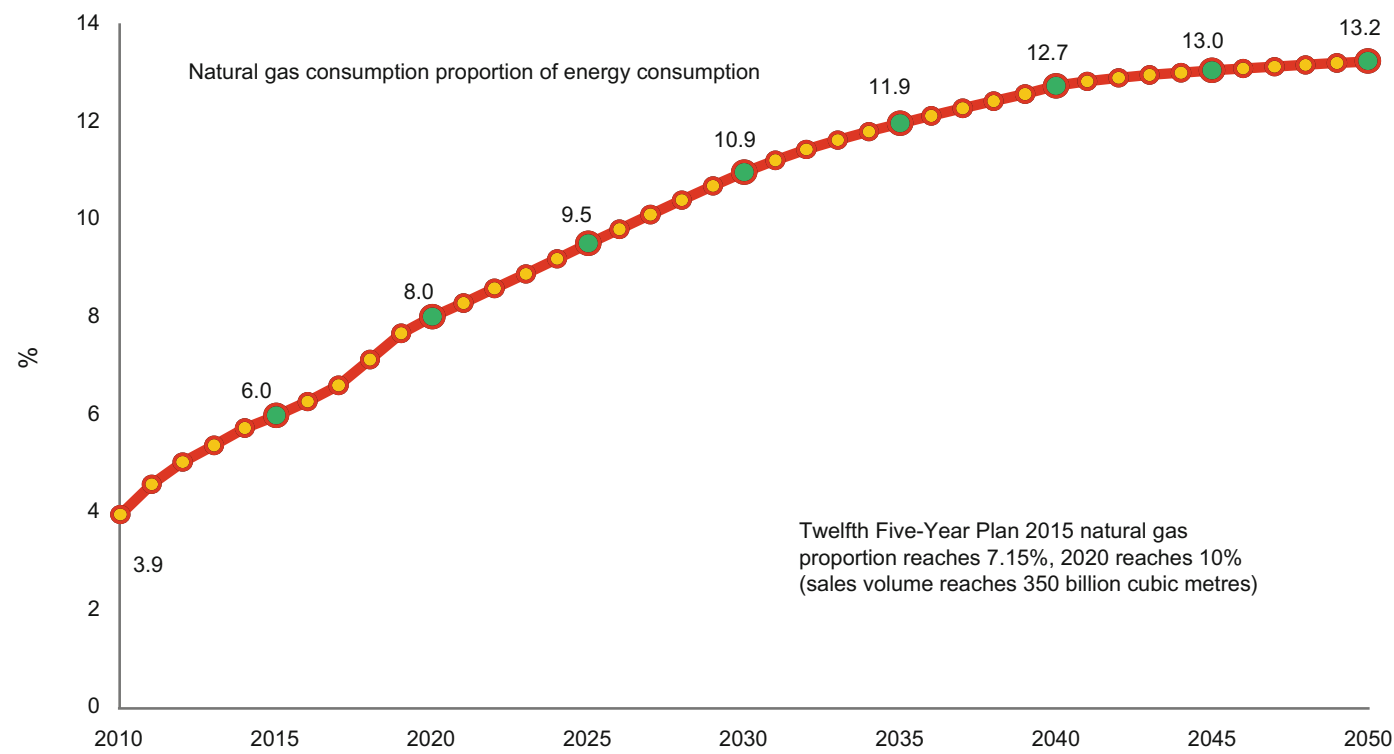

Fig. 5.11 Medium- to long-term changes in ratio of natural gas consumption in China. Data source Results from model calculation

generation. In the standard scenario, the biggest growth lies in nuclear power, while there is also much room for growth for natural gas power generation. Natural gas power generation will rise quickly from 77 billion $\mathrm{kWh}$ in 2010 to
280 billion $\mathrm{kWh}$ by 2020,620 billion $\mathrm{kWh}$ by 2030 and around 920 billion $\mathrm{kWh}$ by 2050 . Similarly, wind power, photovoltaic electricity, hydroelectricity and nuclear power will also undergo rapid development (Fig. 5.12). 


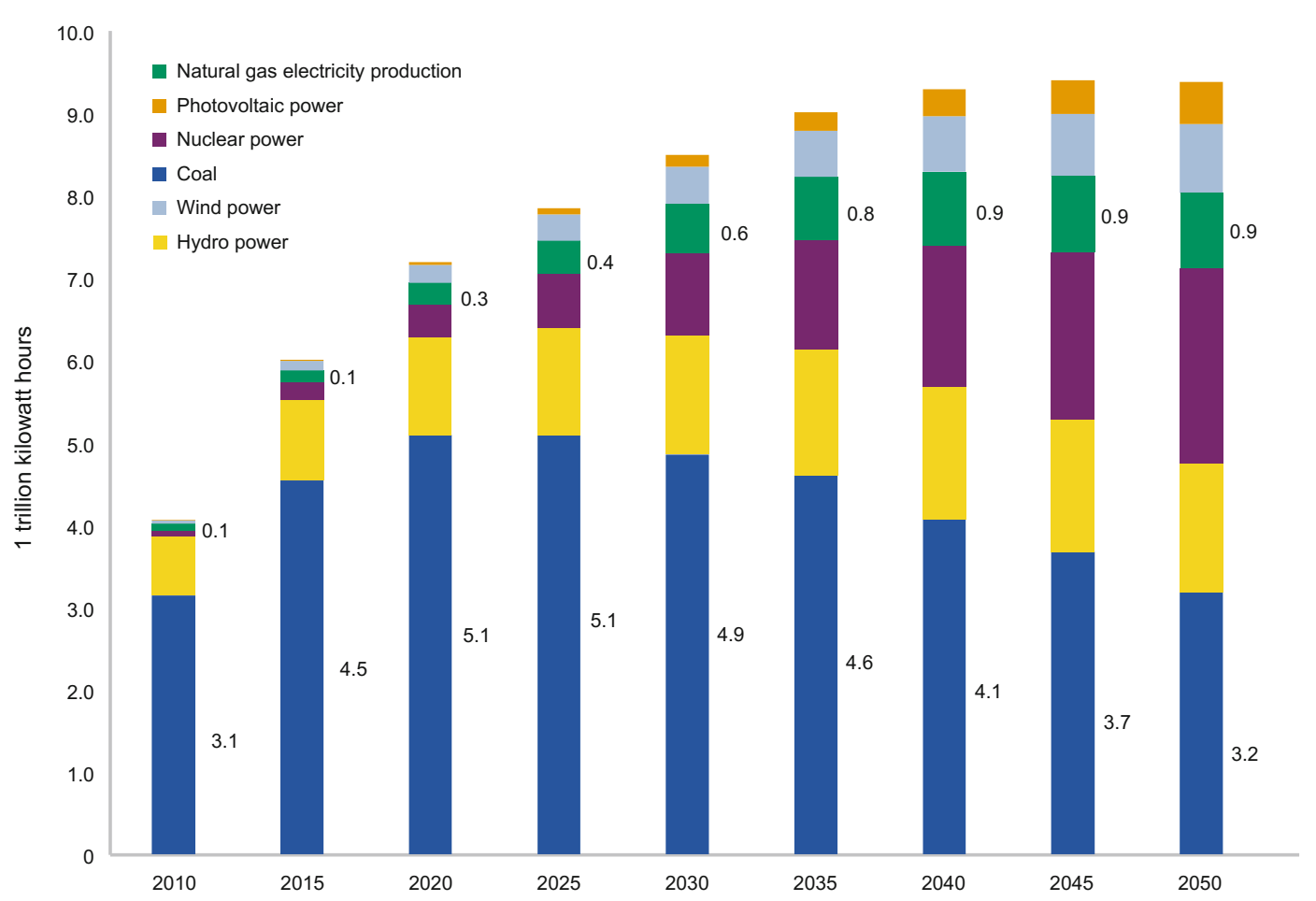

Fig. 5.12 Medium- to long-term power generation structural changes in China. Data source Results from model calculation

\subsection{Natural Gas Supply and Demand in the Policy-Driven Scenario}

In the standard scenario, even though natural gas consumption in China will rise to 300 billion $\mathrm{m}^{3}$ by 2020,450 billion $\mathrm{m}^{3}$ by 2030 and 600 billion $\mathrm{m}^{3}$ by 2050 , it would still not reach the goals set out for natural gas development in the mediumto long-term energy development plan of the 12th Five-Year Plan. This indicates that, in order to achieve those goals, in addition to the current arrangements for energy sources, policies that are more effective must be put in place to boost natural gas demand.

\subsubsection{Total Natural Gas Supply and Demand}

Among the various possible economic measures, the most effective would be the much-vaunted pricing policy based on carbon trading and other ways of realising a carbon price. Under the pressure of a global push for reduction of greenhouse gas emissions, the introduction of a carbon tax could help to encourage society to reduce its reliance on fossil fuels and reduce greenhouse gas emissions. The use of natural gas produces much less carbon than coal or oil, and thus carbon pricing will help to further promote the replacement of coal and oil with natural gas.

In the policy-driven scenario, the demand for natural gas will increase, due to changes in relative energy source prices that are advantageous to natural gas. Due to the sensitivity of natural gas to pricing depending upon different uses, the increase in demand encountered will vary. Some uses, such as household use of natural gas, already contribute a substantial proportion, and thus the increase would be limited in these areas. Other uses, such as power generation and heating, which are more sensitive to pricing, will see a greater relative increase in demand (Fig. 5.13). 


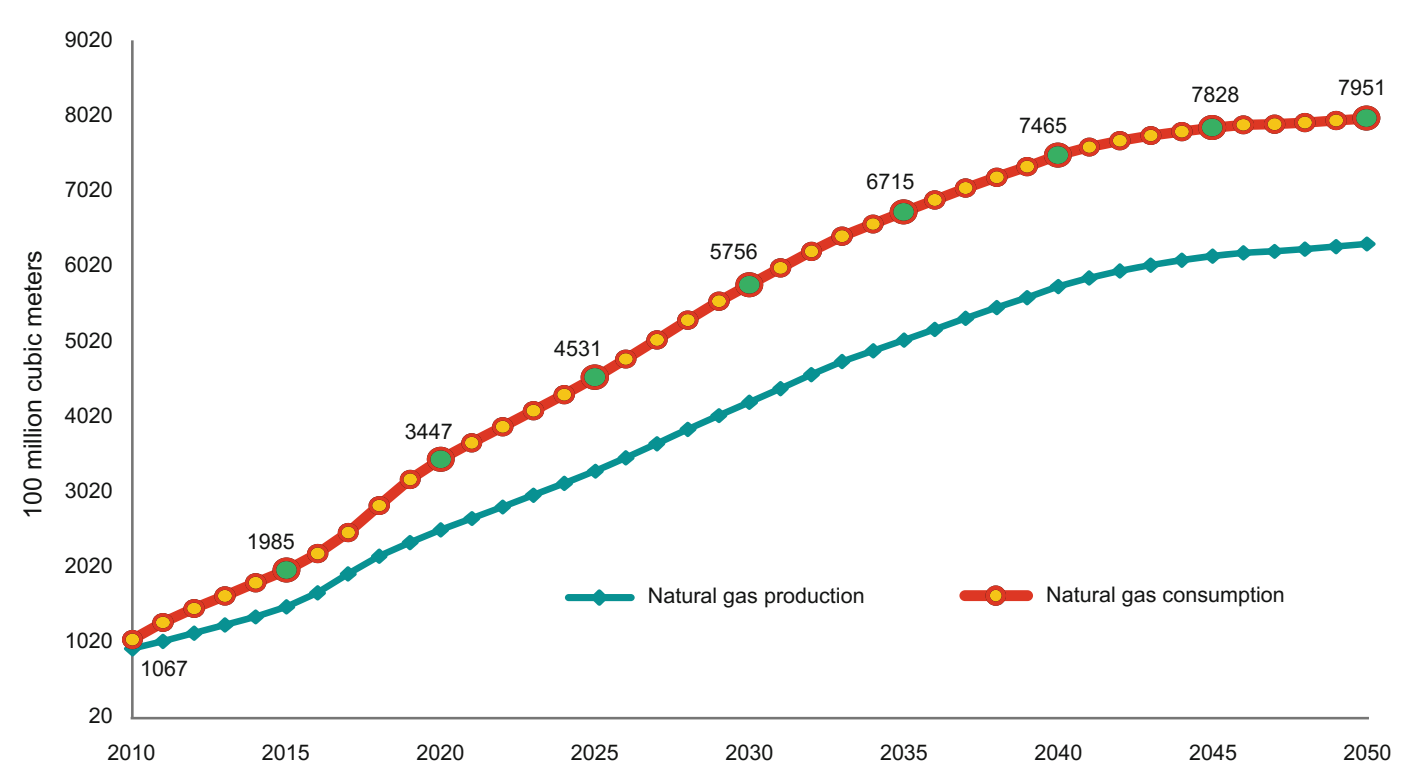

Fig. 5.13 Natural gas supply and demand in the policy-driven scenario. Data source Results from model calculation

With the right policies in place, natural gas demand in China could be expected to reach 344.7 billion $\mathrm{m}^{3}$, achieving the planned goal of 350 billion $\mathrm{m}^{3}$ stipulated in the 12 th Five-Year Plan. By 2030, natural gas consumption may approach the level of 580 billion $\mathrm{m}^{3}$, and be around 800 billion $\mathrm{m}^{3}$ by 2050 .

\subsubsection{Effects on Pollutant Discharge of Natural Gas Consumer Demand Growth}

Under the influence of policy, demand for natural gas will grow and will replace major coal applications, so the use of natural gas will be effective to some degree in restricting emissions of various pollutants (Fig. 5.14).

Based on emissions of 2.46 tons of $\mathrm{CO}_{2}$, $8.5 \mathrm{~kg}$ of $\mathrm{SO}_{2}$ and $7.4 \mathrm{~kg}$ of nitrogen oxides for every one ton of standard coal burned (when approaching zero emissions, each one ton of standard coal burned results in $0.14 \mathrm{~kg}$ of $\mathrm{SO}_{2}$ and $1.12 \mathrm{~kg}$ of nitrogen oxides), under the policy-driven scenario, natural gas consumption will increase from 183 billion $\mathrm{m}^{3}$ in 2014 to 575.6 billion $\mathrm{m}^{3}$ by 2030 , equivalent to at least
522 million tons of standard coal based on calorific value. Based on this, it would be possible to reduce emissions to 418 million tons of $\mathrm{SO}_{2}$ and 4.354 million tons of $\mathrm{CO}_{2}$ (replacing $20 \%$ of near-zero emission coal-fired power generation and $80 \%$ of dispersed coal use) by 2030. This is the equivalent of $21.3 \%$ of the national $\mathrm{SO}_{2}$ emissions total of 20.439 million tons in 2013. There will also be a reduction in nitrogen oxides emissions of 2.339 million tons, which is the equivalent of $10.5 \%$ of the national nitrogen oxides emissions total of 22.274 million tons in 2013. Moreover, by 2020 there will be further reductions of $\mathrm{CO}_{2}$ emissions by 172 million, of $\mathrm{SO}_{2}$ emissions by 1.794 million tons and of nitrogen oxide emissions by 964,000 tons.

In a policy-driven environment, it is possible to markedly reduce greenhouse gas emissions. In a baseline scenario, greenhouse fossil fuel energy consumption in China is expected to continue to grow in terms of emissions in China each year from the 13th Five-Year Plan to 2030. In 2015, greenhouse gas emissions caused by fossil fuels are expected to reach 9.51 billion tons (due to carbon exchange and other factors, greenhouse gas emissions caused by fossil fuel consumption 


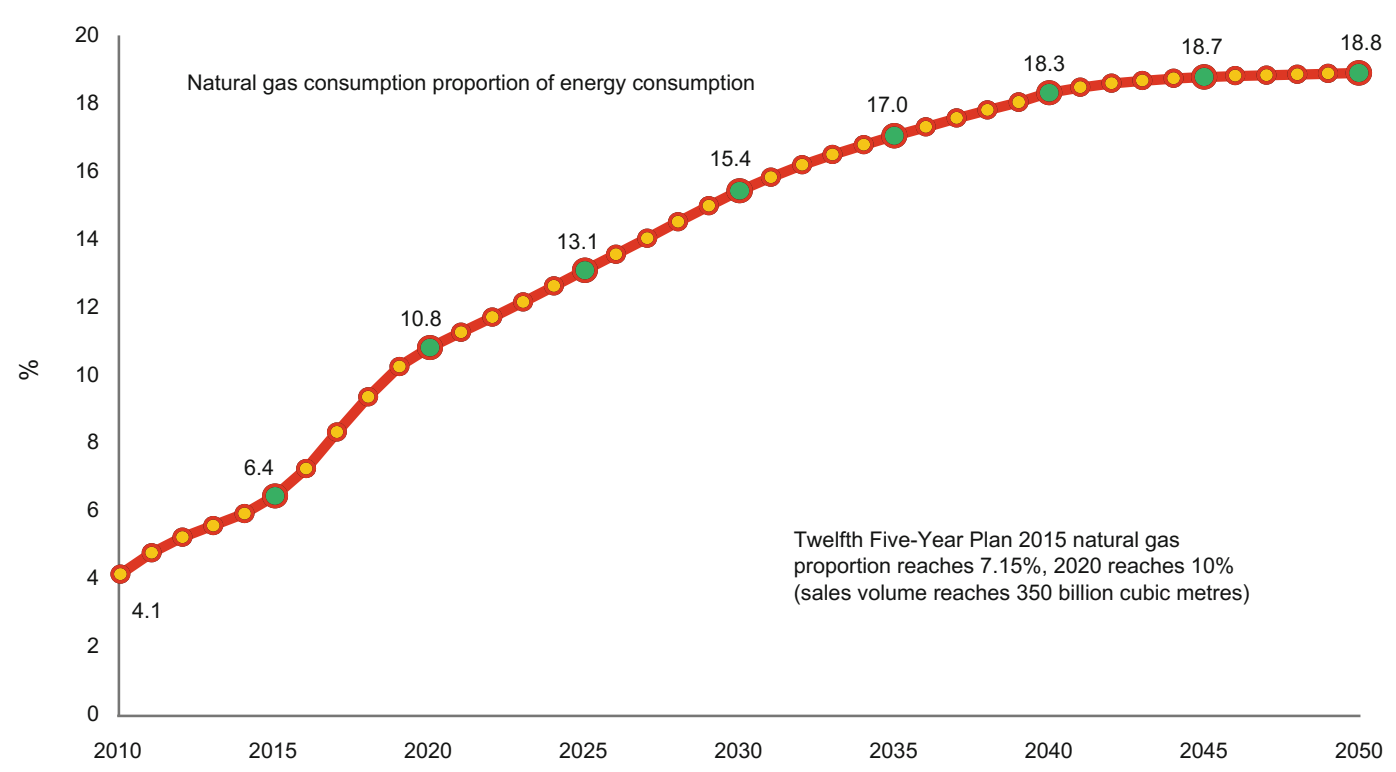

Fig. 5.14 Ratio of natural gas in total energy sources in the policy-driven scenario. Data source Results from model calculation

is not equivalent to the total national emissions total), and by 2020 will approach 10.5 billion tons, an annual increase of $1.93 \%$. By 2030 it will approach 11 billion, growing annually by $0.95 \%$ from 2020 to 2030 , peaking in 2033 at approximately 11.08 billion tons. Subsequently it will gradually decline. In a policy-driven environment, because overall fossil fuel energy consumption will see a major reduction, the resulting greenhouse gas emissions also markedly drop. In 2015, there is expected to be a reduction in emissions of approximately 400 million tons compared to the baseline scenario. $\mathrm{CO}_{2}$ emissions reductions from 2020 to 2030 will be approximately 1.7 billion tons.

\subsubsection{Main Areas of Natural Gas Demand}

In the policy-driven scenario, areas where natural gas demand would grow quickly are still the ones more sensitive to costs and prices, namely natural gas power generation, transport and the chemicals industry, while changes in demand remain relatively small in other areas such as domestic use. For example, with the policies in place, compared to the standard scenario, domestic use would only rise by 5 billion $\mathrm{m}^{3}$ by 2050 , while for natural gas power generation the consumption in 2030 would be 45 billion $\mathrm{m}^{3}$ higher compared to the standard scenario. Natural gas heating possesses tremendous potential and is very sensitive to costs. With policies in place it could be hoped that consumption might rise by 30 billion $\mathrm{m}^{3}$ by 2030 .

Based on the simulation results, in the policy-driven scenario natural gas consumption in China reaches 600 billion $\mathrm{m}^{3}$ by 2030 . Of that total, urban use (including vehicular and waterborne transport) accounts for 35\%, while $32 \%$ goes to power generation, $27 \%$ to industrial fuels and $6 \%$ is used in the chemicals industry. Urban use mainly consists of cooking, hot water for everyday use, gas use in public utilities (airport, government departments, staff canteens, kindergartens, schools, hostels, hotels, restaurants, malls, offices etc.), centralised heating, centralised air conditioning and being used by vehicles and ships. As for industrial use, natural gas is used as fuel for equipment used in various industries, including pottery, glass, steel, 
petrochemicals, textiles, aluminium oxide, titanium dioxide, fire-resistant materials, carbon resources and so on. In the chemicals industry, natural gas is mainly used as an ingredient for the synthesis of ammonia and methanol and in hydrogen production. In power generation, natural gas is used in peak regulation power stations, thermal power stations and by distributed energy source users. There is, therefore, massive potential natural gas demand (Table 5.5).

\subsubsection{Demand Curve for Natural Gas in China in 2030}

\section{Predicted replacement energy source price series}

With consideration given to the long-term trends in international oil prices, this analysis is based on an international oil price of $\$ 80$ per barrel (Table 5.6).

\section{Demand curve for natural gas in $\mathbf{2 0 3 0}$}

The demand for natural gas in China in 2030 is expected to be 576.6 billion $\mathrm{m}^{3}$, subdivided between 31 provinces and 16 types of user. Assessment of terminal natural gas price tolerance for all users in all provinces was carried out based on the local price of replacement energy sources. Conversion was then carried out based on the Shanghai benchmark price conversion, with the natural gas price tolerance based on the Shanghai benchmark being ranked from high to

Table 5.5 Natural gas consumption based on primary usage (100 million $\mathrm{m}^{3}$ ) according to use

\begin{tabular}{|c|c|c|c|c|c|c|}
\hline \multicolumn{2}{|c|}{ Major fields of application } & \multicolumn{2}{|l|}{2013} & \multicolumn{2}{|l|}{2030} & \multirow{2}{*}{$\begin{array}{l}\text { Growth } \\
(\%)\end{array}$} \\
\hline & & Consumption & $\begin{array}{l}\text { Proportion } \\
(\%)\end{array}$ & Consumption & $\begin{array}{l}\text { Proportion } \\
(\%)\end{array}$ & \\
\hline \multirow[t]{3}{*}{ Urban gas } & $\begin{array}{l}\text { Residential } \\
\text { living }\end{array}$ & 181 & 11.0 & 520 & 9.03 & 187 \\
\hline & $\begin{array}{l}\text { Commercial } \\
\text { services }\end{array}$ & 104 & 6.3 & 300 & 5.21 & 188 \\
\hline & $\begin{array}{l}\text { Centralised } \\
\text { heating }\end{array}$ & 97 & 5.9 & 360 & 6.25 & 271 \\
\hline \multirow{4}{*}{$\begin{array}{l}\text { Vehicular and } \\
\text { waterborne } \\
\text { transport }\end{array}$} & CNG taxis & 59 & 3.6 & 160 & 2.78 & 171 \\
\hline & CNG buses & 32 & 1.9 & 90 & 1.56 & 181 \\
\hline & LNG lorries & 33 & 2.0 & 550 & 9.56 & 1567 \\
\hline & LNG vessels & & & 45 & 0.78 & \\
\hline \multirow[t]{3}{*}{$\begin{array}{l}\text { Natural gas } \\
\text { electricity } \\
\text { production }\end{array}$} & $\begin{array}{l}\text { Peak } \\
\text { regulation } \\
\text { power stations }\end{array}$ & 157 & 9.5 & 640 & 11.12 & 308 \\
\hline & $\begin{array}{l}\text { Thermal } \\
\text { power stations }\end{array}$ & 126 & 7.6 & 1060 & 18.42 & 741 \\
\hline & $\begin{array}{l}\text { Distributed } \\
\text { energy sources }\end{array}$ & 4 & 0.2 & 130 & 2.26 & 3150 \\
\hline \multicolumn{2}{|l|}{ Industrial fuel } & 606 & 36.7 & 1540 & 26.75 & 154 \\
\hline \multirow{3}{*}{$\begin{array}{l}\text { Natural gas } \\
\text { chemical } \\
\text { engineering }\end{array}$} & Ammonia & 152 & 9.2 & 185 & 3.21 & 22 \\
\hline & Methanol & 61 & 3.7 & 106 & 1.84 & 74 \\
\hline & $\begin{array}{l}\text { Hydrogen } \\
\text { production etc. }\end{array}$ & 41 & 2.5 & 70 & 1.22 & 71 \\
\hline \multicolumn{2}{|c|}{ Total natural gas consumption } & 1653 & 100 & 5756 & 100 & 248 \\
\hline
\end{tabular}

Data source Results from model calculation 
Table 5.6 Natural gas energy source replacement price list by province (calculated at the international oil price of $\$ 80$ per barrel)

\begin{tabular}{|c|c|c|c|c|c|c|c|c|c|c|}
\hline \multirow[t]{2}{*}{ No. } & \multirow[t]{2}{*}{ Region } & $\begin{array}{l}\text { Coal } \\
\text { price }\end{array}$ & $\begin{array}{l}\text { Fuel } \\
\text { oil } \\
\text { price }\end{array}$ & $\begin{array}{l}\text { Naphtha } \\
\text { price }\end{array}$ & $\begin{array}{l}93 \# \\
\text { petrol } \\
\text { retail } \\
\text { price }\end{array}$ & $\begin{array}{l}0 \# \\
\text { diesel } \\
\text { retail } \\
\text { price }\end{array}$ & $\begin{array}{l}\text { Small } \\
\text { bottle } \\
\text { LPG } \\
\text { price }\end{array}$ & $\begin{array}{l}\text { Large } \\
\text { bottle } \\
\text { LPG } \\
\text { price }\end{array}$ & $\begin{array}{l}\text { Industrial } \\
\text { electricity } \\
\text { consumption } \\
\text { price }\end{array}$ & $\begin{array}{l}\text { Household } \\
\text { electricity } \\
\text { consumption } \\
\text { price }\end{array}$ \\
\hline & & \multicolumn{3}{|c|}{$(\mathrm{CNY} / \mathrm{t})$} & \multicolumn{2}{|c|}{$(\mathrm{CNY} / \mathrm{L})$} & \multicolumn{2}{|c|}{$(\mathrm{CNY} / \mathrm{kg})$} & \multicolumn{2}{|l|}{ (CNY/kWh) } \\
\hline 1 & Xinjiang & 316 & 2553 & 7096 & 5.86 & 5.74 & 7.19 & 6.83 & 0.36 & 0.53 \\
\hline 2 & Gansu & 507 & 2553 & 7155 & 6.01 & 5.85 & 7.24 & 6.88 & 0.46 & 0.51 \\
\hline 3 & Qinghai & 519 & 2553 & 7252 & 6.00 & 5.86 & 7.24 & 6.88 & 0.36 & 0.45 \\
\hline 4 & Tibet & 507 & 2727 & 7083 & 6.00 & 5.86 & 8.20 & 7.79 & 0.36 & 0.45 \\
\hline 5 & Ningxia & 478 & 2553 & 6959 & 6.03 & 5.83 & 5.76 & 5.48 & 0.43 & 0.45 \\
\hline 6 & Shaanxi & 450 & 2553 & 7126 & 6.01 & 5.83 & 6.30 & 5.98 & 0.55 & 0.50 \\
\hline 7 & Shanxi & 460 & 2595 & 6988 & 6.08 & 5.88 & 7.62 & 7.24 & 0.50 & 0.48 \\
\hline 8 & $\begin{array}{l}\text { Inner } \\
\text { Mongolia }\end{array}$ & 444 & 2595 & 7080 & 6.04 & 5.83 & 7.62 & 7.24 & 0.48 & 0.47 \\
\hline 9 & Henan & 565 & 2594 & 6990 & 6.04 & 5.85 & 6.86 & 6.52 & 0.60 & 0.56 \\
\hline 10 & Hubei & 628 & 2594 & 6993 & 6.04 & 5.85 & 8.49 & 8.07 & 0.60 & 0.57 \\
\hline 11 & Hunan & 606 & 2594 & 6997 & 6.08 & 5.90 & 8.03 & 7.63 & 0.65 & 0.59 \\
\hline 12 & Jiangxi & 666 & 3722 & 6990 & 6.07 & 5.88 & 6.85 & 6.51 & 0.65 & 0.60 \\
\hline 13 & Anhui & 674 & 3722 & 6985 & 6.06 & 5.87 & 6.93 & 6.58 & 0.65 & 0.57 \\
\hline 14 & Yunnan & 539 & 2727 & 7018 & 6.18 & 5.98 & 7.62 & 7.24 & 0.48 & 0.48 \\
\hline 15 & Guizhou & 506 & 2727 & 6991 & 6.16 & 5.95 & 8.20 & 7.79 & 0.51 & 0.46 \\
\hline 16 & Sichuan & 561 & 2727 & 7028 & 6.19 & 6.02 & 7.28 & 6.91 & 0.58 & 0.47 \\
\hline 17 & Chongqing & 534 & 2727 & 6974 & 6.19 & 6.01 & 6.98 & 6.64 & 0.63 & 0.52 \\
\hline 18 & Guangdong & 675 & 3548 & 6992 & 6.09 & 5.89 & 8.23 & 7.82 & 0.69 & 0.61 \\
\hline 19 & Guangxi & 677 & 3548 & 7000 & 6.14 & 5.94 & 8.44 & 8.02 & 0.59 & 0.53 \\
\hline 20 & Fujian & 661 & 3722 & 6982 & 6.08 & 5.89 & 7.98 & 7.58 & 0.61 & 0.45 \\
\hline 21 & Hainan & 678 & 3548 & 6960 & 6.14 & 5.94 & 8.19 & 7.78 & 0.66 & 0.61 \\
\hline 22 & Jiangsu & 632 & 3722 & 6978 & 6.07 & 5.86 & 7.40 & 7.03 & 0.64 & 0.53 \\
\hline 23 & Zhejiang & 701 & 3722 & 6978 & 6.07 & 5.88 & 8.14 & 7.73 & 0.65 & 0.54 \\
\hline 24 & Shanghai & 615 & 3722 & 6946 & 6.35 & 6.24 & 7.20 & 6.84 & 0.69 & 0.62 \\
\hline 25 & Beijing & 580 & 2595 & 6953 & 6.36 & 6.26 & 7.62 & 7.24 & 0.62 & 0.49 \\
\hline 26 & Tianjin & 580 & 2595 & 6950 & 6.03 & 5.83 & 7.62 & 7.24 & 0.63 & 0.49 \\
\hline 27 & Hebei & 596 & 2595 & 6993 & 6.03 & 5.83 & 7.02 & 6.67 & 0.56 & 0.52 \\
\hline 28 & Shandong & 556 & 3722 & 6988 & 6.03 & 5.84 & 7.81 & 7.42 & 0.67 & 0.55 \\
\hline 29 & Liaoning & 499 & 2891 & 7352 & 6.03 & 5.83 & 7.47 & 7.09 & 0.53 & 0.50 \\
\hline 30 & Jilin & 645 & 2891 & 7320 & 6.03 & 5.83 & 6.51 & 6.18 & 0.58 & 0.53 \\
\hline 31 & Heilongjiang & 623 & 2891 & 7394 & 6.03 & 5.83 & 6.33 & 6.01 & 0.58 & 0.51 \\
\hline
\end{tabular}




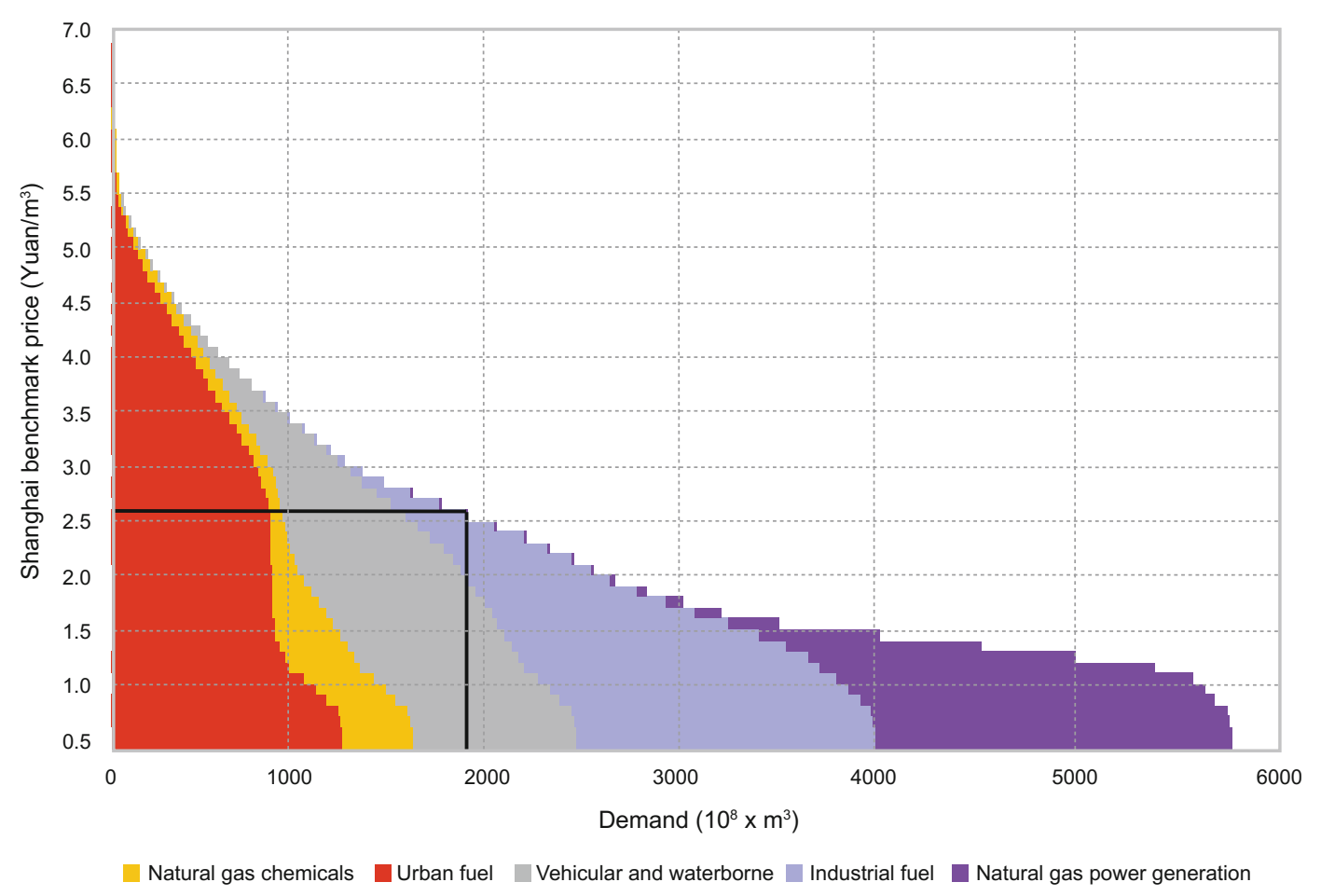

Fig. 5.15 Demand curve for natural gas in China in 2030

low, yielding the demand curve for natural gas in China in 2030 (Fig. 5.15).

\section{Various integrated policies would be required in order to achieve a $\mathbf{5 7 5 . 6}$ billion $\mathbf{m}^{3}$ natural gas consumption}

If a pricing policy is not implemented, achieving a target of 575.6 billion $\mathrm{m}^{3}$ of natural gas consumption by 2030 would require a series of alternative policies to be introduced. Based on the national natural gas pricing reform plan of 2013 , with an international oil price of $\$ 80$ per barrel as the basis, it is calculated that the benchmark Shanghai natural gas price would be 2.6 $\mathrm{CNY} / \mathrm{m}^{3}$. Looking at the effective demand curve for natural gas, the planned natural gas consumption in China by 2030 would be 575.6 billion $\mathrm{m}^{3}$, and with reference to the benchmark Shanghai natural gas price of $2.6 \mathrm{CNY} / \mathrm{m}^{3}$ and effective consumption of 206.7 billion $\mathrm{m}^{3}$, this would account for $32 \%$ of estimated demand. Urban natural gas centralised heating, power generation, synthesis of ammonia and methanol, and the majority of usage as fuel in other industries would not satisfy the conditions for generation of effective demand capacity based on the benchmark Shanghai natural gas price of 2.6 CNY $/ \mathrm{m}^{3}$ (Table 5.7).

At the current energy source pricing levels, market forces alone would not push demand for natural gas up to the goal of 575.6 billion $\mathrm{m}^{3}$. Systematic design of policy which reflects the environmental and social value of natural gas is necessary. 
Table 5.7 Market demand for natural gas in China in 2030 (100 million cubic metres)

\begin{tabular}{|c|c|c|c|c|c|c|}
\hline \multicolumn{2}{|c|}{ Major fields of application } & \multicolumn{2}{|l|}{2030} & \multicolumn{2}{|c|}{$\begin{array}{l}2030 \text { market demand (no } \\
\text { policy measures) }\end{array}$} & \multirow{2}{*}{$\begin{array}{l}\text { Actual } \\
\text { degree } \\
(\%)\end{array}$} \\
\hline & & Consumption & $\begin{array}{l}\text { Proportion } \\
(\%)\end{array}$ & Consumption & $\begin{array}{l}\text { Proportion } \\
(\%)\end{array}$ & \\
\hline \multirow[t]{3}{*}{ Urban gas } & $\begin{array}{l}\text { Residential } \\
\text { living }\end{array}$ & 520 & 9.03 & 516 & 28.30 & 99 \\
\hline & $\begin{array}{l}\text { Commercial } \\
\text { services }\end{array}$ & 300 & 5.21 & 292 & 16.02 & 97 \\
\hline & $\begin{array}{l}\text { Centralised } \\
\text { heating }\end{array}$ & 360 & 6.25 & & & \\
\hline \multirow{4}{*}{$\begin{array}{l}\text { Vehicular and } \\
\text { waterborne } \\
\text { transport }\end{array}$} & CNG taxis & 160 & 2.78 & 160 & 8.77 & 100 \\
\hline & CNG buses & 90 & 1.56 & 90 & 4.93 & 100 \\
\hline & LNG lorries & 550 & 9.56 & 366 & 20.09 & 67 \\
\hline & LNG vessels & 45 & 0.78 & 10 & 0.57 & 23 \\
\hline \multirow[t]{3}{*}{$\begin{array}{l}\text { Natural gas } \\
\text { generation }\end{array}$} & $\begin{array}{l}\text { Peak } \\
\text { regulation } \\
\text { power stations }\end{array}$ & 640 & 11.12 & & & \\
\hline & $\begin{array}{l}\text { Thermal } \\
\text { power stations }\end{array}$ & 1060 & 18.42 & & & \\
\hline & $\begin{array}{l}\text { Distributed } \\
\text { energy sources }\end{array}$ & 130 & 2.26 & & & \\
\hline \multicolumn{2}{|l|}{ Industrial fuels } & 1540 & 26.75 & 315 & 17.29 & 20 \\
\hline \multirow{3}{*}{$\begin{array}{l}\text { Natural gas } \\
\text { chemical } \\
\text { engineering }\end{array}$} & Ammonia & 185 & 3.21 & & & \\
\hline & Methanol & 106 & 1.84 & 2 & 0.12 & 2 \\
\hline & $\begin{array}{l}\text { Hydrogen } \\
\text { production etc. }\end{array}$ & 70 & 1.22 & 70 & 3.84 & 100 \\
\hline \multicolumn{2}{|c|}{ Total natural gas consumption } & 5756 & 5756 & $100 \%$ & 1824 & 100 \\
\hline
\end{tabular}

Data source Results from model calculation

Open Access This chapter is licensed under the terms of the Creative Commons Attribution 4.0 International License (http://creativecommons.org/licenses/by/4.0/), which permits use, sharing, adaptation, distribution and reproduction in any medium or format, as long as you give appropriate credit to the original author(s) and the source, provide a link to the Creative Commons license and indicate if changes were made.
The images or other third party material in this chapter are included in the chapter's Creative Commons license, unless indicated otherwise in a credit line to the material. If material is not included in the chapter's Creative Commons license and your intended use is not permitted by statutory regulation or exceeds the permitted use, you will need to obtain permission directly from the copyright holder.

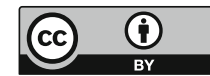

